\title{
SOME OBSERVATIONS ON THE THEOLOGICAL ANTHROPOLOGY OF ISAAC OF NINEVEH AND ITS SOURCES
}

\section{Introduction}

The anthropological outline of Isaac of Nineveh (7th century) is based primarily on Theodore of Mopsuestia and Evagrius Ponticus, authors who are well known to represent very different, if not contradictory, anthropologies: Antiochian and Alexandrian, respectively. Isaac of Nineveh belongs to the large tradition of East Syriac mystics that flourished from the middle of the seventh century through the end of the ninth century and he is one of the most original theoretical minds among the exponents of this literary movement, like John of Dalyatha, Dadisho Qatraya, Joseph Hazzaya, etc. With regard to its relation to the Alexandrian and Antiochian legacies of Christian thought, this movement as a whole is characterised by a fertile synthesis of the thought of Evagrius Ponticus and of Theodore of Mopsuestia. While the latter had been the main christological and exegetical authority in the East Syriac Church since the last decades of the 5th century, the former became only gradually an authority in matters of ascetical practice and spirituality. It was probably the School of Nisibis, where most of the East Syriac bishops and high clergy received their theological education in the 6th century, that imparted to these two authors such outstanding authority. ${ }^{1}$ Babai the Great, in the introduction to his Commentary on Evagrius' Capita Gnostica, gives us a testimony of their authority by referring to Theodore and Evagrius as "teachers of

(1) This article is a revised form of a paper presented at the "Third Annual Archbishop Iakovos Graduate Student Conference in Patristic Studies" organized by the Stephen and Catherine Pappas Patristic Institute of the Holy Cross Greek Orthodox School of Theology in Brookline, Massachusetts (March 15-17, 2007).

Cf. A. H. Becker, Fear of God and the Beginning of Wisdom: the School of Nisibis and Christian Scholastic Culture in Late Antique Mesopotamia (Philadelphia, 2006) 113-126 and 175-178. 
the church." ${ }^{2}$ Of course, the substantial differences between these two theologies could not have escaped the attention of the best East Syriac theologians, who tried in fact to mediate between them. ${ }^{3}$

This short article intends to contribute to a better understanding of the explicit and, mostly, implicit answers that Isaac of Nineveh gives to the question of what a human being is. In order to understand Isaac's own thesis one would have to investigate the way in which he modifies his main theological sources, namely Theodore and Evagrius, and uses them to compose a new synthesis. In this article I will try to make only a rough sketch of his synthetical method of working, which I intend to investigate further on, ${ }^{4}$ at the risk of sacrificing accuracy and completeness. Nevertheless, I hope to focus on the most important elements of Isaac's anthropology.

\section{The Character of Isaac's Anthropology}

Isaac of Nineveh considers Man as a being whose existence is based on his relationship with God. In Isaac's thought Man's constitutive components, according to the common concepts of Late Antiquity, i.e. a body and a two-part or three-part soul, become, as it were, different means of communication in the all-inclusive relationship between God and humans, losing thus their "ontological independence." Accordingly Isaac is not especially interested in defining these components or describing in an exact manner the activities assigned to each. On the contrary, he is rather inconsistent in using anthropological or psycho-

(2) Babai the Great, Commentary on the Capita Gnostica (W. Frankenberg (ed.), Evagrius Ponticus, AGWG.PH NS XIII.2 (Berlin, 1912), 17).

(3) L. АвRAмошsкI, "Der Stupor, der das Gebet unterbricht" - Evagrius, Cent. Suppl. 30, in Übersetzung, Original (?) und Interpretation, in: M. TAMСKe, A. HeInz (Hrsg.), Zu Geschichte, Theologie, Liturgie und Gegenwartslage der syrischen Kirchen (Münster-Hamburg - London, 2000) 15-32, here: 25.

(4) A thorough investigation of this subject would need to overcome a number of essential difficulties: firstly, Isaac did not expose his anthropology or his theological thought on the whole in a clearly structured dogmatic treatise, but rather in numerous mostly short passages scattered in his voluminous Oeuvre, so that the researcher has to reconstruct the outline of his "system" by comparing his sometimes seemingly inconsistent statements; secondly, the anthropologies of both of his precursors have not been sufficiently explored, in spite of the progress of research in patristics in the last 4-5 decades, one of the reasons being the precarious state of the surviving sources (on these difficulties as regards Theodore of Mopsuestia, see F. G. McLeod, The Image of God in the Antiochene Tradition (Washington, D.C., 1999) 63). 
logical notions and, as observed by Sebastian Brock, does not follow the terminological distinctions that had already been established by the Syriac mystical authors of earlier centuries, whose work Isaac had read. ${ }^{5}$ That's why it would seem inadequate to begin studying Isaac's anthropology by analysing the role he assigned to the mentioned components of the human being. Therefore, bearing in mind Isaac's view that the existence of the human being consists in his relationship with God, the first question to be posed should rather be: what are the milestones in the relationship between Man and God? Only a preliminary answer to this question could help answer the question of Man's Being. ${ }^{6}$ In Isaac's work, as well as in a significant part of patristic literature, the answer to the former question should be sought primarily in the interpretation of three main points: Man's creation as God's image, the fall of Man as parting from his Creator, and the eschatological salvation that has already occurred in Christ and is, at the same time, still to be expected. Isaac rarely writes on the creation of humans in an explicit manner, as is expected from a work of ascetical monastic literature. However, it is quite clear that he considers the creation of Man as a second stage of the Creator's work, subordinated to the creation of the immaterial angels. ${ }^{7}$ But this subordination - applying, remarkably enough, only to this present world - is a subordination within an ontological communion of humans and angels, since both are conceived of as being noetic natures. Isaac refers to the angels after almost every general statement about humans, underlining thus this ontological communion between them. ${ }^{8}$

(5) S. BRocK, "Introduction" to his translation: Isaac of Nineveh (Isaac the Syrian), "The Second Part", Chapters IV-XLI (CSCO 555) (from now on cited as: BRock) XVII.

(6) Cf. S. Chinlà, Dall' ascesi eremitica alla misericordia infinita - Ricerche su Isacco di Ninive e la sua fortuna (Firenze, 2002) 150-158; cf. J. В. Снавот, De S. Isaaci Ninivitae vita, scriptis et doctrina (Louvain, 1892) 73-79.

(7) See II, 3.2.7. The Latin number refers to the "Second Part" of Isaac's works, the first Arabic number to the number of the Discourse (the "Second Part" includes 41 Discourses); as the third Discourse of the "Second Part" contains 4 units with one hundred Capita Gnostica each, the second Arabic number refers to these 4 units, while the third Arabic number refers to the number of the cited Capitum. When the cited passage comes from the Discourses 4-41 of the "Second Part," that have been edited and translated from Sebastian Brock, I cite his translation (see footnote 5); when the cited passage comes from the Discourses 1-4, that haven't been edited yet, the translation is mine.

(8) See e.g. II, 3.1.35; II, 3.1.43; II, 3.2.71. 


\section{Isaac's Anthropology and its Sources}

\subsection{The Influence of Theodore of Mopsuestia: Creation and Fall}

According to Isaac, humans were created mortal already in the first place: "We are not mortal because we sinned; but because we are mortal, we fall into sin. The power of freedom stands between the path of life and the path of death; and one can only chose one of these two ways." 9 This is a thesis of Theodore of Mopsuestia, ${ }^{10}$ which enjoyed broad reception among East Syriac theologians. ${ }^{11}$ Isaac defends this even against the letter of the Bible: "Furthermore, the Scripture says that death would not have been introduced to our nature, if Adam had not sinned, although it is obvious that humans were created mortal already before they sinned, as testified by their natural constitution."12 In what sense does the "natural constitution" of humans testify to their mortality? Isaac's view on this point can only be reconstructed on the basis of the following passage from the surviving fragments of Theodore's commentary on Genesis: "The [corporal] form of masculine and feminine [humans] shows by itself, that [God] was equipping Man for the mortal life, as this form demonstrates from the very beginning, potentially, the making of children."13

In developing further his thought on the biblical connection between sin and death, Isaac also interprets the biblical narration of the fall of Man in a way that is considerably different from the letter of the Scripture: "It was not disobedience which introduced death to the house of Adam, nor did transgression remove them from Paradise, for it is clear that God did not create Adam and Eve to be in Paradise, just a small portion of the earth; rather, they were going to subjugate the entire earth."14 And how should one interpret the biblical narration, in which the expulsion from Paradise and the curse of death are explicitly presented as

(9) II, 3.3.2.

(10) See the Greek fragments of Theodore's commentary on Genesis: PG 66, 633-646, esp. 641.

(11) See e.g. Ph. Gignoux, Introduction, in: Narsai, Homélies sur la création (Turnhout, 1968) (PO 34, 3/4) 501-502.

(12) II, 3.4.89.

(13) See PG 66, 641; cf. A. Ziegenaus, Das Menschenbild des Theodor von Mopsuestia (München, 1963) 65-81; cf. A. Vööвus, Regarding the Theological Anthropology of Theodore of Mopsuestia, Church History 32 (1964) 115-124, here 117-118; cf. J. Dewart, The Theology of Grace of Theodore of Mopsuestia (Washington, D.C., 1971) 37-40.

(14) II, 39.4 (Ввоск, 164). 
God's punishment for Adam's and Eve's disobedience? According to Isaac - who is once again following Theodore, ${ }^{15}$ - God acts in this narration like a teacher, who hides the truth from his immature pupils for their own good: "Just as He decreed death, under the appearance of a sentence, for Adam because of sin, and just as He showed that the sin existed by means of the punishment - even though this punishment was not His real aim: He showed it as though it was something which Adam would receive as a repayment for his wrong, but He hid its true mystery, and under the guise of something to be feared, He concealed His eternal intention concerning death and what His wisdom was aiming at: even though this matter might be grievous, ignominious and hard at first, nevertheless in truth it would be the means of transporting us to that wonderful and glorious world. Without it, there would be no way of crossing over from this world and being there." 16

God's acts are "pedagogically" hiding the truth in a double sense: He makes humans believe, firstly, that they are being punished for their disobedience with the death penalty, and, secondly, that death is terrible. One should mention here the traditional patristic view of death as a necessary evil, which is good inasmuch as it does not allow sin to be perpetuated. ${ }^{17}$ Nevertheless, Isaac's view differs significantly from the traditional one, as it considers death as the means of entering the future world of eschatological fulfillment, lending thus to death a definitively positive accent that prevails over the negative one.

This interpretation of God's action towards humans as a sort of "pedagogical" tactic is however not limited to the narration of Genesis - or to the Bible altogether, - but can be expanded to God's revelation towards human beings in this world as a whole: "So you should see that, while God's caring is guiding us all the time to what He wishes for us, as things outwardly appear it is from us that He takes the occasion for providing, His aim being to carry out by every means what He has intended for our advantage. All this is because He knew beforehand our inclination towards all sorts of wickedness, and so He cunningly made the harmful consequences which would result from this into a means of entry to the future

(15) See the summary of Theodore's "Contra defensores peccati originalis" (CPG 3860) given by Photius of Constantinople: R. Henry (ed.), Photius, Bibliothèque, t. II (Paris, 1960) 177-183, here esp. 179.

(16) Ibid.

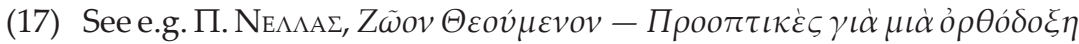

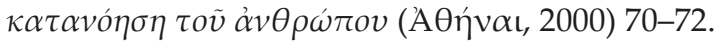


good and the setting right of our corrupted state. These are things which are known only to him."18

The creation of human beings on an ontological level inferior to that of angels, the incompleteness of their existence, marked by mortality, and even sinfulness, understood as a consequence of mortality, were necessary in order to enable humans (as well as angels) to perceive the true magnitude of the world-to-come and realize, thanks to the insight into their own sinfulness, that they have not earned this magnitude themselves and do not deserve it in any way. ${ }^{19}$ Isaac does not argue any further for this conception of the history of creation, which is at least partially inspired by Theodore. The reader is probably supposed to accept it as the mystery of the present world; in the future world, says Isaac, an explanation of this mystery will be simply superfluous. ${ }^{20}$

From this basic thesis of God's "mono-causality" in the history of creation, Isaac, with admirable consistency, draws the following conclusions concerning human existence:

1. Even "the inclination to evil/to $\sin ^{\prime 21}$ in the human being (and in the angels) is an integral part of God's plan. The passions contesting the ascetics are consequently "a service to God," with the exception of pride, understood apparently as a refusal to conform with God's plan for the world. ${ }^{22}$ Nevertheless, a person is always responsible for his decision to translate a sinful inclination into action.

2. Free will, which was described by church fathers like Gregory of Nyssa as being the peak of God's image in human beings and has been passionately defended also by Theodore of Mopsuestia against Jerome's doctrine of the original sin, plays only a minor role in Isaac's anthropology. ${ }^{23}$ As a matter of fact, there are several passages in his surviving works that seem to negate, more or less openly, its importance. ${ }^{24}$ In two passages of his Capita Gnostica, which put up for discussion the relation between human ascetical effort and divine Grace, Isaac refor-

(18) II, 39.5 (Ввоск 164-165).

(19) See II, 3.4.87.

(20) See II, 3.3.70.

(21) The Syriac expression goes back to the Syriac translation of Theodore's works (see Вrock, 165, n. 5).

(22) See II, 3.4.23.

(23) Cf. R. A. Norris, Manhood and Christ - a Study in the Christology of Theodore of Mopsuestia (Oxford, 1963) 173-190.

(24) See e.g. II, 5.2 (ВRоск, 6-7). 
mulates his relativizing treatment of free will into an aspect distinction: while from a human point of view Grace comes as an answer to human effort, from God's point of view Grace is always there, even if one fails to perceive its presence. But the human point of view is at the same time right and wrong, while God's point of view is of course always right. ${ }^{25}$

3. This aspect distinction, deduced from the ascetical experience, corresponds to Isaac's observations on the history of salvation as a whole ${ }^{26}$. Although God, according to the letter of the Scripture, seemingly reacts to the acts of human beings, He truly acts, according to Isaac, only on His own initiative and always in accordance with His own original plan for the advantage of humans. God appears as a retaliator not only in the Scriptures, but also in the personal experience of many humans with this same goal, namely the greatest possible advantage of those needing such a representation of God in order to achieve some spiritual progress..$^{27}$ Following Theodore of Mopsuestia and the entire East Syriac tradition, ${ }^{28}$ Isaac sees God as a pedagogue and the creation as a school.

4. The real freedom of a human being consists in self-transcendence, in a "crossover" to God's own freedom; that is, real freedom is an aspect of deification. Through the ascetical way of life under "the law of freedom, ${ }^{29}$ the human will must be purified with permanent exercise in discerning good inclinations from bad ones and thus be liberated from all passions of body and soul. In this way, thanks to the indwelling of the Holy Spirit, the human being can furthermore reach a level of liberty that supersedes every law and effort of the will, because the one who "entered the field of the Holy Spirit" is not steered any more by his own will, but by the will of God..$^{30}$ However, in this world this kind of freedom can only be given temporarily, as a foretaste of the world-to-come. ${ }^{31}$

(25) See II, 3.3.16 and II, 3.3.18.

(26) It is this fundamental aspect distinction that makes it possible to reconcile Isaac's treatment of free will with his confirmation of human responsibility for sin.

(27) See II, 3.1.11.

(28) See Th. Heinthaler, Die verschiedenen Schulen, durch die Gott die Menschen lehren wollte. Bemerkungen zur ostsyrischen Schulbewegung, in: M. Tамске (Hrsg.), Syriaca II (Münster, 2004) 175-192.

(29) See II, 14.34 (Вrоск, 77).

(30) See II, 3.2.49.

(31) See II, 2.6. 


\subsection{The Influence of Evagrius Ponticus: God's Image in Man and its Fulfilment}

According to a patristic interpretation of Genesis 1:26, deification, as the process of becoming like God, is the realization of God's image in the human being. Consequently, the notion of deification itself presupposes an interpretation of the statement, humans are an image of God, or, in a more symbolical language, an answer to the question of the proper place of God's image in the human being.

Theodore of Mopsuestia, in contrast to the theology represented by many church Fathers (e.g. Gregory of $\mathrm{Nyssa}^{32}$ ) and most of all by the Alexandrian tradition, ${ }^{33}$ held that God's image in the human being does not consist of the noetic part of the soul. ${ }^{34}$ He argued instead, that the human being is God's image in the sense that he was created to represent Him, the true king of all, in the realm of visible creation, i.e. to rule over the visible world like a caring king. In the visible creation humans represent God, Theodore maintains, just like the images or statues of the emperor standing in the cities of the Roman Empire represented the absent emperor. ${ }^{35}$

Isaac locates God's image in the noetic part of the soul, deviating thus clearly from Theodore's position: "When the Mind gains consciousness of the beauty of its own nature, it begins to grow in the mystical way, in which angels grow. In that moment it is held worthy of receiving the divine revelations and of standing in communion even with the angels. As it stands in the ancient beauty of its nature, that was given to it at the moment of its creation, it receives in a natural manner the theory of its own Prototype." ${ }^{36}$ The Mind comes into contact with the only real image of God, Christ: "The word of the Scripture named Adam an image of God, picturing thus the real fulfillment of this name in Christ." ${ }^{37}$

Isaac's quoted statements exemplify a large number of passages, primarily from his Capita Gnostica, describing the progress of the as-

(32) See Gregory of Nyssa, De hominis opificio XVI (SC 6) 151-161.

(33) See for example A. G. Hamman, "Introduction" to: L'homme icône de Dieu - La Genèse relue par l'Église des Pères (Paris, 1998) 9-53, esp. 31 and 41-42 ; cf. J. Benr, Asceticism and Anthropology in Irenaeus and Clement (Oxford, 2000) 135-151.

(34) Cf. McLeod, The Image of God..., 50-51.

(35) Cf. Ibid., 65-66.

(36) II, 3.2.72.

(37) II, 3.2.67. 
cetic efforts as, firstly, a gradual concentration of the human I in the pure or naked Mind, achieved through the gradual transcendence of sensory perception, of ethically indifferent everyday thoughts, and then also of all dianoetical acts, and secondly, as a restitution of the original noetic nature of humans, which represents the bond of all humans with the Son, the Paradigm of all Minds. This description of the ontological background of the ascetical way of life goes back to Evagrius Ponticus. Evagrius had developed this as an integral part of a holistic doctrine, systematizing under Origenian influences all the main contents of Christian dogmatics, from creation and fall to incarnation, from passion and resurrection to the eschatological salvation. ${ }^{38}$ Isaac had studied thoroughly Evagrius' so-called Letter to Melania and his Capita Gnostica - both in Syriac translation - as the large number of quotations and loans from both works clearly demonstrates. ${ }^{39}$ Evagrianism has been of fundamental importance for East Syriac mystical theology on the whole.

\section{Isaac's Synthesis of the Two Traditions}

The doctrinal elements that Isaac borrowed, as shown, from his two main sources are enough to make visible the difficulties inherent in any attempt of reconciling these different anthropological approaches. Under the originally platonic presupposition, that the Noetic is immortal - a presupposition that was, as is well known, widely accepted in late antique theology and is, seemingly at least, also shared by Isaac - the Evagrian conception of the human being as a noetic nature appears at first sight to be incompatible with the Theodore's interpretation of Genesis, maintaining that human beings were created mortal. This contradiction becomes all the more evident, if one considers the systematic framework, to which the mentioned doctrinal elements belong. One only has to think e.g. on the one hand of the primate of eschatology in Theodore's thought, that conceives of the proceeding of human history as a continuous progress from the initial imperfection of the present state-of-being towards the fulfilment of All in the future state-of-being, and on the other hand to think of the Evagrian theory of human history as the process of reaching again the original state of perfect unity of all minds in the divine Mind, a state that was

(38) Cf. A. Guillaumont, Les "Kephalaia Gnostica" d' Évagre le Pontique et l'histoire de l'Origénisme chez les Grecs et chez les Syriens (Paris, 1962) 37-39.

(39) Cf. Chialà, Ricerche su Isacco di Ninive..., 101-113. 
disrupted by the "original sin" of the minds. ${ }^{40}$ Isaac was surely well aware of these important discrepancies between his two main sources. How did he attempt to overcome them?

Isaac makes the mediation between the anthropological approaches of Theodore and of Evagrius possible first of all by not borrowing the latter's thought, that the material world emerged as a result of the fall of noetic beings from their original oneness in God. This thought - together with the concept of creation - is a central aspect of the Evagrian theory of the emergence of the visible world. ${ }^{41}$ This reduction of the cause of the material world to the original sin of spiritual beings would be completely incompatible with the consistent cosmological and anthropological optimism of Isaac, for whom the development of God's history with humans is an uninterrupted progress towards the fulfilment of All in the new world, so that even "the fall of Man," Adam's sin, is only apparently a failure. On the other hand, Isaac adopts neither Theodore's doctrine on the meaning of God's image in human beings, nor its central notion of man's free will.

Isaac took his entire concept (based on a certain Bible hermeneutics) of the history of salvation from Theodore, while borrowing from Evagrius the description of God's relationship with humans in terms of the ontology of Mind. Correspondingly, he had to omit Theodore's ontological-anthropological positions, as well as Evagrius' speculative "history of Being." By these significant omissions, Isaac deprived both anthropologies of their character as "closed" holistic systems; in this way, he was able to combine them as different, more complementary than contradictory, aspects of his own anthropological synthesis. Isaac reads Theodore's history of salvation as an anthropology "from below," and Evagrius' ontology as an anthropology "from above," exploiting thus the possibilities of a dialectical mediation that were already inherent in the thought of his two precursors and in the two theological traditions they represent.

(40) One may consider as a counterweight to this pronounced Protology the Evagrian theory of eschatological perfection, leading the minds to a state of absolute equality in the Holy Spirit that will be even superior to their original unity in the divine Mind. This theory makes the temporary structures of the created Being, even of the spiritual one, appear rather relative and provisional.

(41) Cf. Guillaumont, Les “Kephalaia Gnostica"..., 42. 


\section{SUMMARY}

This article intends, firstly, to point out the high tensions between the Evagrian and Antiochian (Theodoran) lines of anthropological thought in Isaac of Nineveh's work. Isaac develops an "unconventional" anthropology, that goes back in its main points to Theodore of Mopsuestia's interpretation on the biblical narrative of Man's creation and fall: according to Isaac, Man was created as a mortal being and his fall was from the very beginning a part of God's plan of salvation, whose eschatological aim consists in the elevation of the whole mankind to a radicaly new state of eternal being in God's love, after death and through death. But at the same time Isaac maintains, following the Evagrian tradition, that the human being has been created as a spiritual substance, who has to redeem his fall by returning to his original natural state of being in Christ. This article attempts to demonstrate how Isaac tries to combine these two that different traditions in a new anthropological synthesis. 